\title{
The Evolution and Growth of the Concept of Corporate Social Responsibility
}

\author{
Vaijayanti Sharma ${ }^{1}$ \\ ${ }^{1}$ Symbiosis Law School, Pune, Maharashtra, INDIA
}

\begin{abstract}
The corporate world has been a steady and concrete unit builds on motives aiming towards generation of profits for years on. In the latter half of the 20th century there has been a demand and understanding of the need for stability and sustainability of business guided on principles of social stimulation and aiding practices in lieu of the same. While there has been no universally applicable definition of the term 'Corporate social Responsibility', With the introduction of various strategies like Carroll's four layer Pyramid (1991) and the inclusion of Section 135 of the recently implemented Indian Companies Act, 2013, Corporate social Responsibility has evolved in terms of its scope as well as legitimacy, which the author seeks to establish. The paper also analysis various driving forces, external as well as internal, within small companies like start ups, which guide them to put equal weight age to profit and social responsibility and achieve all corporate goals in the process. The paper mainly focuses on the Indian scenario and the fast growing need to balance corporate growth with social growth for the purpose of development along with societal upliftment. The analysis of the concept will be supported by examining economic, legal, ethical and philanthropic aspects associated with it. The author attempts to study the bridges built between the corporate and society along the years and the impact it has created. This scope of impact will be coupled with the possible growth chart of CSR as a concept and further a device to be implemented in the smallest corporate units in the country, furthering mutual sustainable development of the corporate and society.
\end{abstract}

Keywords: Corporate Social Responsibility, Sustainability, Carroll's Four Layer Pyramid(1991),Start Ups, Societal Upliftment

\section{Introduction}

With the advent of new economic and financial plans for structural stability and market superiority in company's throughout the world, the concept of corporate social responsibility rests on a credible foundation and acts as an instrumental tool to achieve these goals differentially. There has been a plethora of debates and discussion surrounding the concept and whether it affects primary economic priorities of the corporate sector. As the impact and consequences have already been elaborated upon previously through various literature and other discussion panels, the author in the paper wishes to chart the evolution and development of corporate social Responsibility and thus the resultant change in corporate social dynamics in the $21^{\text {st }}$ century. There is an assessment of ethical considerations vis-a-viz growing corporate competitiveness through the lens of an age of widespread communication and transparency. This is coupled with the relatively recent trends wherein organisations no longer isolate them with socio-economic prosperity. More recently legislative changes have also put the pressure on corporate to imbibe corporate socialist directives as part of its functioning and goals. This is resulting in even newly set up companies being motivated to voluntarily adopt corporate social responsibility.

The author thus relying on credible foundation of CSR practices highlights the bridge created between the evolution of CSR and thus it turning into an issue interesting all levels of the corporate sector equally. The literature discussed also relates to the concept being a short term policy adaption leading to long term sustainable development, and thus preparing organisation to withstand the test of time. 


\section{Models And Charters}

Since the inception of the school of thought that rooted for CSR the term expands and manifests itself to be synonymous with 'corporate social performance'[Dr. Marieta Olaru,2012 ${ }^{1}$ ] , 'corporate social integrity', corporate social policy' and 'sustainable corporate governance'[D'Amato, Henderson and Florence ${ }^{2}$. The present findings and results are based on roots founded in models of corporate social responsibility. The same have been discussed as follows.

\subsection{Carroll's CSR Pyramid and its applications ${ }^{3}$}

Various researches have assessed CSR quantitatively as well as qualitatively throughout the $20^{\text {th }}$ as well the $21^{\text {st }}$ century. But the model most popularly used to establish fundamental CSR objectives and criteria is the one presented by Carroll in 1983. The analysis presented is in the form of a pyramid structure. It sets out to be a streamlined and structure not only terminological inconsistencies but also fill the void created previously from scattered isolated works of individuals with no universally applicable model.

According to Carroll "corporate social responsibility involves the conduct of a business so that it is economically profitable, law abiding, ethical and socially supportive. To be socially responsible then means that profitability and obedience to the law are foremost conditions when discussing the firm 's ethics and the extent to which it supports the society in which it exists with contributions of money, time and talent".

Each layer of the pyramid suggests a different types of obligation that is expected to be followed by businesses

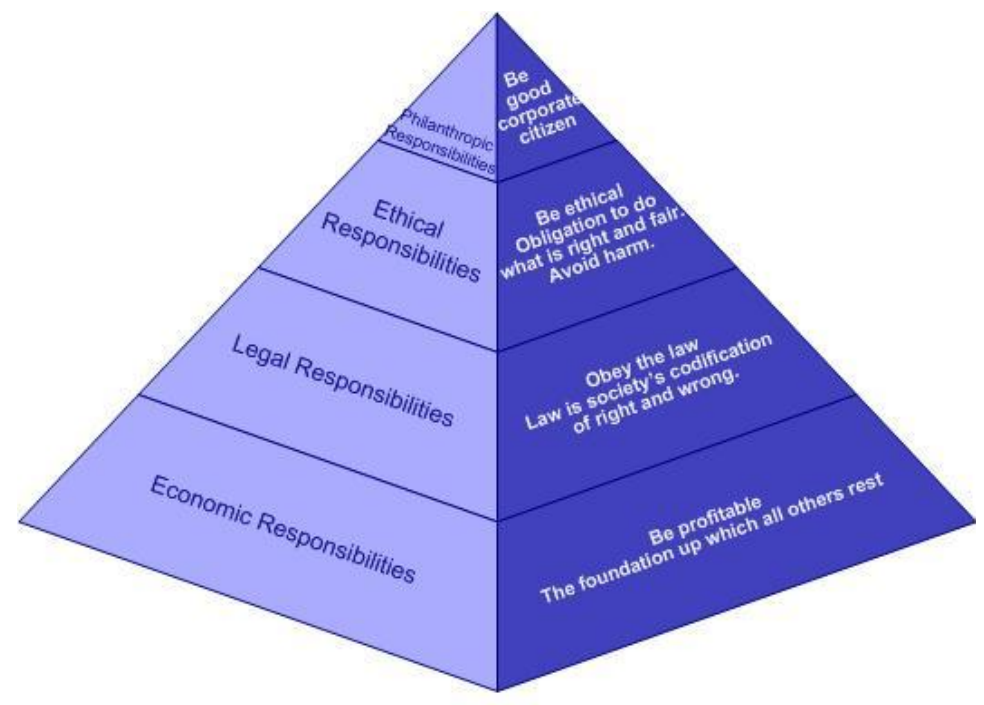

Fig. 1: Use "Carroll's CSR Pyramid Structure"

- .Economic Responsibility: The presumption regarding this layer lies in the fact that businesses have the responsibility to generate profits. But in actuality the focus is on compelling the businesses to utilize the profit responsibly in terms of creation of economic opportunities like preserving economic interest of shareholders, creating job opportunities with financial equality, and finally proper functioning of the business. The other layers rest upon this layer.[Novak, 1996]

- Legal Responsibility: the emphasis on this obligation is self explanatory. There is an implied binding on companies to abide by laws and legislation. In the current scenario this implicates into the formulation of anti corruption laws[Coco-Cola: Anti Corruption legislation], unfair trade practices and competition laws.

- Ethical Responsibility: this concept was elaborated upon by Carroll herself in 1991 wherein the scope was expanded. There was an emphasis on inherent ethical behavior by companies. In the Shell Company 
incident of 1990s there was an instant inference of this obligation where the decision of the government was reversed for disposing of oil platform after a campaign and disagreement by the society and public.

- Philanthropic Responsibility: being on top of the pyramid, this layer is slightly narrower in scope. It concerns itself with more strategic implementation of earned wealth in a responsible manner. Improving quality of life for the society as a whole is a matter of independent study. There is also an inclusion of controversial and intellectual debate within companies on strong leadership roles of specific people on top level posts. Theories relating to leadership and CSR are slowly emerging. [Waldman et al 2004 ${ }^{4}$ ]

\subsection{United Nations Global Impact of CSR}

Relying on the Carrolls Pyramid of CSR, this specific project was hailed by the UN Secretary General Kofi Annan at the World Economic Forum in Davos, December 31, 1999 It issues guidelines based on the principles of corporate social responsibility.

- Human rights: the recognition of human rights by the UN as a business concern opened several avenues for CSR to be adopted as a legitimate practice across the globe. The charter has directed companies like Pepsico ltd to bring about human rights plan of action termed the human rights workplace policy'

- Anti Corruption: Ban all forms of corruption including bribery and extortion AND

Legal responsibility, Planetary(global) responsibility, Environmental Responsibility, Cultural \& Ethical Responsibility and Philanthropic Responsibility

\subsection{Companies Act 2013 (India)}

The Ministry of Corporate Affairs has recently notified Section 135 and Schedule VII of the Companies Act as well as the provisions of the Companies (Corporate Social Responsibility Policy) Rules, 2014 (CRS Rules) which has come into effect from 1 April 2014. The policy relies on give and take of resources. The ideology is that by performing Socialist activities the companies give back to the society, from which it gains it basic resources.

\section{CSR Through The Years}

The concept of corporate social responsibility formally spans across almost 60 years. Throughout this period, there has been extensive research and analysis revolving around the topic resulting in newer and developed formulation of the concept. Though defined research texts and materials came into the limelight in the 1940's, even a cursory glance of the 'The Social Responsibilities of Business' by Morrell Heald ${ }^{5}$ beginning from the 1900 s depicts that the conscious of the citizens became more sensitive towards the ethical and social behaviour of corporations. The reason behind needing to understand the evolution of CSR is the explicit change of political, social and economic dynamics throughout the decades, across the Globe. As the playing field changes, the game is bound to have modifications parallel to those changes. Due to the growing understanding of the socio economic rationale CSR today has gained immense importance.CSR has thus gone through rigorous screening in terms of laying the foundation and evolving effective principles to be universally applied. The evolution of the same has been can be seen in the table below . 
TABLE I: CSR Timeline

\begin{tabular}{|c|c|c|c|c|}
\hline Concept Evolved & Year & Author & Work & Keywords \\
\hline Social Responsibility & 1953 & Bowen & $\begin{array}{l}\text { Social Responsibilities of a } \\
\text { Businessman }\end{array}$ & $\begin{array}{l}\text { Socially responsible Business Decisions, Long } \\
\text { term Effect, Social Consciousness }\end{array}$ \\
\hline $\begin{array}{l}\text { Corporate Social } \\
\text { Responsibility }\end{array}$ & 1960 & Davis & Iron Law of Responsibility ${ }^{7}$ & $\begin{array}{l}\text { Reasoning, Managerial Context, Socially } \\
\text { Responsible Outlook }\end{array}$ \\
\hline $\begin{array}{l}\text { Social Responsibility } \\
\text { Construct }\end{array}$ & 1975 & $\begin{array}{l}\text { Friedman, } \\
\text { Carroll }\end{array}$ & $\begin{array}{l}\text { The social responsibility of } \\
\text { business is to increase its } \\
\text { profits }^{8}, \text { CSR Pyramid }\end{array}$ & $\begin{array}{l}\text { Social Action, Social and Civic and moral } \\
\text { obligation, economic concept of Responsibility }\end{array}$ \\
\hline $\begin{array}{l}\text { Corporate Social } \\
\text { Responsiveness }\end{array}$ & 1985 & $\begin{array}{l}\text { Aupperle, } \\
\text { Carroll, } \\
\text { Hatfield }\end{array}$ & $\begin{array}{l}\text { An Empirical Investigation } \\
\text { Of The Relationship Between } \\
\text { CSR \& Profitability }\end{array}$ & $\begin{array}{l}\text { Four Part Definition, economic: legal, ethical and } \\
\text { discretionary, Concern For Society, Go beyond, } \\
\text { Corporate Social Performance }\end{array}$ \\
\hline $\begin{array}{l}\text { Corporate Social } \\
\text { Performance (CSP) }\end{array}$ & 1991 & Wood & A Model of $\mathrm{CSP}^{10}$ & $\begin{array}{l}\text { Corporate Sustainability, meeting economic and } \\
\text { non economic goals, Business Ethics }\end{array}$ \\
\hline Corporate Citizenship & $2000 \mathrm{~s}$ & $\begin{array}{l}\text { Logsdon } \\
\text { Wood }\end{array}$ & Stakeholder Theory ${ }^{11}$ & $\begin{array}{l}\text { Corporate governance, Human Capital, ethical } \\
\text { Consumption }\end{array}$ \\
\hline
\end{tabular}

\subsection{Phases in India}

Corporate social responsibility in India has been an age old practice with changes in terminology and scope. While roots of social contribution by purely capatilist bodies can be traced back to chanakyas time when employee benefits were considered to boost morale, the formal introduction of the concept has been more recent. CSR has gone through 4 phases in India. Though these phases are distinct and structurally divided, a lot of the ideas overlap into each other.

- Phase I: This phase pans out from the 1850 s all the way to the beginning of $20^{\text {th }}$ century. Right from pre industrialization times when merchants gave away part of their wealth for social welfare. But what was the start of formal CSR initiative is when by the end of $19^{\text {th }}$ century Industrialized families like the Tata, Godrej, Bajaj, Modi, Birla, Singhania were strongly inclined towards economic as well as social considerations.

- Phase II: this phase is marked with the advent of the independence movement. CSR was not a formally coined termed but was disguised behind the term 'trusteeship' given by Mahatma Gandhi which simply meant that industry men should manage their wealth in order to benefit the common man. Thus there began a chain of Socio economic Developmental initiatives.

- Phase III: As the Indian Economy began to take shape as a mixed economy, CSR started to evolve accordingly. 1960s onwards the private sector had a minimal role to play in the economic scenario and thus Public Sector Undertakings played a pivotal role. Workshops regarding CSR started being conducted to dictate policy of transparency and social accountability due to increased public stakeholders. But what was a breakthrough in formally initiating CSR activities was the inclusion of clause 80G of the Income Tax Act, 1961 which allows certain tax deductions to companies that donate to charitable institutions. This further motivated companies to adopt CSR.

- Phase IV: the fourth phase has seen more development of CSR as a Business Concept as it has seen in the previous three phases. Even though they lay a foundation, companies decide to forego the traditional CSR concepts restricted to public welfare and adapted schemes of sustainable business models. Liberalization Privatization Globalization became a game changer with the economy and thus there were 
systematized works describing CSR policies like, a conceptual study of CSR development in India. In D.B. Patil \& D.D. Bhakkad, Redefining Management Practices and Marketing in Modern Age Dhule, India: Atharva Publications (p. 152-154). \} further The companies Act was amended to include S135 as a mandate for companies.

\section{Hypothesis}

Tracing CSR through time has definitely been insightful in order to understand how it has to become a successful business instrument with retrospective positive effect on the society. Moving from an informal and voluntary practice it has become a legally binding and structured practice for the corporate. This leading road has come to a point where business do not question the idea of CSR at all and strive to achieve the Goal with as much precision as they can. This applies to business that are new to the game and that are just starting out in terms of being a part of the market. Yet they take up the risk of allocating wealth towards social, legal and moral responsibilities. Startup companies have shown immense promise for reformation in socioeconomic sense and this has been possible only due to an early start that is right from their inception. Hence the author proposes that, "Start Up companies will adopt Corporate Social Responsibilities from their very inception no matter the risk involved."

\section{Findings And Results}

With S135 of the Companies Act being enforced, isolated donations and social actions though might complete the requirement of legislative directives, are not sufficient for terming the Completion of CSR. Each Company depending on nature of their business, location of their factories and similar factors are developing robust plans with a view to long term economic development. The Goal in mind is to achieve sustainability as well as superiority in terms of competitiveness. As per industry estimates a total of Rs 20,000 crore was spent on CSR activities out of which $10 \%$ was the contribution of Startups. Expansion of CSR ultimately leads to long term development of society and therefore results in expansion of market and consequent growth of demand.

In a Report published by Brain and company in 2013 it has been discussed in detail how philanthropic initiatives and experience in the work sector are not exactly related. While experience helps, younger generation has greater influence on relatives and show great potential for inviting more donors. Thus young entrepreneurs are increasingly being recognized as being great catalysts for social development. Companies like Ola, Zomato and Paytm were instrumental in providing flood relief in the recent Chennai floods incident. Lightbox, an early stage capital venture holds a strong CSR policy with managerial strategy and implementation. Snapdeal, at the time of its release opened up a microsite called Sunshine which catered to charities and which now is associate with various NGOs and grows exponentially. Ever since 2013 Paytm has a strategy and uses a specific metric, which sanctions organizations working on social causes. The company has been involved in causes like doubling customer donations, book a smile and outreach programme in Kashmir. CSR has recently manifested itself in relation to the 'Swachh Bharat Campaign' the campaign requires capital investment both in terms of human as well as economic. Construction start-ups who do not have heavy capital to invest can use this opportunity to start construction projects on smaller scale. The even though these companies shell out a specific profit margin to invest in these activities the author observes the following reasons for the same

- Building Strong Public Relations: when companies decide to invest in social causes it speaks to customers on a deeper level. People have an inherent consciousness to contribute towards social welfare in any way they can. Thus this provides for a larger customer base and economic opportunity for the company which is the first motivator in adapting CSR initiatives. 
- Employee Retention: Philanthropic achievements of companies make its employees pride themselves on the fact that they are on some level or the other being a philanthropist and social servant themselves. Thus they develop solidarity to such companies.

- Reputation and Goodwill: as a startup there is an increased pressure on the company to get recognition in an already crowded market. Indulging in CSR helps give companies a competitive edge and build a pristine reputation in the market.

- Stock value and Shareholders Interest: while one cannot quantify Social responsibility, but CSR definitely indicates the social and economic accountability and sustainability of the company. Sustainability is definitely one of the main points that shareholders look for in predicting future profitability and life of a company.

Thus it becomes patent that there are a wide range of reasons why startups take up CSR initiatives, thereby climbing up the pyramid by completing each responsibility. Economic responsibilities are fulfilled when all the aforementioned activities directly contribute to economic growth of the company and thereby ensure the targeted profits. Further companies need to ensure legality of procedure when dealing with the public so closely. For maintaining good reputation and employee retention, companies enforce codes of conduct and strong policies against illegal activities. Further the ethical and philanthropic responsibilities are easily fulfilled when the company has a strong legal, and economic standing. CSR activities can be funded and planned and adapted. Apart from the deterrence provided by Section 134(8) of the company's act which provides penalties for non compliance of CSR, there is an inherent positive philanthropic culture developed in the corporate world that encourages them to take on CSR.

\section{Conclusion}

The concept of Corporate Social Responsibility has gone through a lot of changes throughout the years but what remains is a long standing testament that social responsibility coupled with fiscal management results in a successful Business strategy. Companies always strive to reach at the top of the pyramid of CSR and thus starting early is always a safe bet. Hence the bridge between the development of CSR and it reaching a point where hesitation to commit to it is eliminated has been build on the stakes of Public relation and sustainability incentive. As social consciousness continues to grow, the concept is only going to escalate in terms of importance and impact, therefore furthering the balance in the corporate world and the society.

\section{Acknowledgements}

I would like to thank Professor Mrs. Shweta Singh, Professor, Symbiosis Law School for sharing her expertise in the subject and guiding my research. I would also like to thank Mr. Nilanjan Sinha, Head of legal Compliance \& Public Affairs, (Indian subcontinent, MARSH) for helping me with the necessary research and analysis of the topic.

\section{References}

[1] Prof. Marieta Olaru, Ph. D., "The Impact Of Corporate Social Responsibility On Business Performance - Can It Be Measured, And If So, How?," in Proc. 2012 THE BERLIN INTERNATIONAL ECONOMICS CONGRESS CONF., pp. 2-6. (Published Conference Proceedings style)

[2] Alessia D'Amato, Sybil Henderson, Sue Florence (2009) on Corporate Social Responsibility and Sustainable Businesses: Guide to Leaders hip Tasks and Functions [Online]. 21(3). pp. 3-11. Available: http://insights.ccl.org/wpcontent/uploads/2015/04/CorporateSocialResponsibility.pdf 
[3] Carroll A. B., "Corporate social responsibility: Evolution of definitional construct. Business and Society”, 199938 (3): 268-295. https://doi.org/10.1177/000765039903800303

[4] Waldman, D, Siegel, D \& Javidan, M, , "CEO Transformational Leadership and Corporate Social Responsibility", (2004), RENSSELAER POLYTECHNIC INSTITUTE

[5] Heald,M, “ The social responsibilities of Business: company and community, (1900-1960), Cleaveland, OH: CASE WESTERN UNIVERSITY PRESS.

[6] Bowen, H.R. “Social Responsibilities of a Businessman”, New York: Harper and Row (1953)

[7] Davis, K. “ Iron Law of Responsibility”, California management Review (1960) Vol 2, (P.70-76) https://doi.org/10.2307/41166246

[8] Friedman M. "The social responsibility of business is to increase its profits", (1970) New York Times Magazine

[9] Aupperele, K.E., Carroll, A.B., \& Hatfield,J.D, “ An Empirical Investigation Of The Relationship Between Corporate Social Responsibility And Profitability,” (1985) ACADEMY OF MANAGEMENT JOURNAL,28, (P. 446-463) https://doi.org/10.2307/256210

[10] Wood, D.J , “ corporate social performance Revisited”, (1991) ACADEMY OF MANAGEMENT REVIEW, 16, (P. 691718) https://doi.org/10.5465/AMR.1991.4279616

[11] Logsdon, Jeanne M., and Donna J. Wood.. "Business Citizenship: From Domestic to Global Level of Analysis." Business Ethics Quarterly (2002) 12(2):155-8 https://doi.org/10.2307/3857809

[12] Brain and company, (2013) on Indian philanthropy [online]. Pp. 1-7. available: http://www.bain.com/Images/BAIN_REPORT_India_Philanthropy_Report_2013.pdf 